\title{
HUBUNGAN KARAKTERISTIK PETANI DAN PERILAKU KOMUNIKASI PETANI DALAM PEMENUHAN INFORMASI USAHATANI LADA DI DESA SUKADANA BARU, KECAMATAN MARGA TIGA, KABUPATEN LAMPUNG TIMUR
}

\author{
(Correlation Between Farmers' Characteristics and Communication Behavior in Fulfilling Pepper \\ Farming Information in Sukadana Baru, Marga Tiga, East Lampung) \\ Kiki Ambarwati, Indah Nurmayasari, Rio Tedi Prayitno
}

Jurusan Agribisnis, Fakultas Pertanian, Universitas Lampung, Jl. Prof. Dr. Soemantri Brojonegoro No.1 Bandar Lampung 35141, Telp. 082186151837, e-mail: indah.nurmayasari@fp.unila.ac.id

\section{ABSTRACT}

The purposes of this study are to determine the communication behavior of pepper farmers, characteristics of pepper farmers and analyze the correlation between farmers' characteristics and communication behavior in fulfilling pepper farming information. This research was conducted in Sukadana Baru Village, Marga Tiga District, East Lampung regency in August 2018. This location was chosen purposively with consideration that Sukadana Baru Village is a village with the largest area and pepper production in East Lampung. The number of samples in this study were 43 pepper farmers. This study used a survey method, and data were analyzed using descriptive analysis and rank Spearman test. The results showed that all respondent farmers were at the productive age level with an average age of 42 years, average level of basic education of 9 years, the average cultivated area of 2.00 hectares, pepper farming experience 22 years, and the average monthly income of Rp2,591,382.00. Communication behavior of farmers in fulfilling pepper farming information fell into the medium category. There was a significant correlation between farmer's age, land size, and income with communication behavior in fulfilling pepper farming information.

Key words: communication behavior,farmer characteristics, pepper

\section{PENDAHULUAN}

Provinsi Lampung merupakan salah satu Provinsi di Indonesia yang paling berkontribusi menjadikan Indonesia sebagai negara produsen utama lada dunia (Ditjenbun 2012). Provinsi Lampung menempati urutan kedua penghasil lada terbesar setelah Provinsi Bangka Belitung. Lada yang dihasilkan oleh Provinsi Lampung adalah lada hitam dengan ciri cita rasa dan aroma yang khas yang telah dikenal di pasar dunia dengan nama "Lampung Black Pepper".

Tanaman lada tersebar dibeberapa kabupaten di Provinsi Lampung. Kabupaten Lampung Timur merupakan salah satu kabupaten di Provinsi Lampung, yang sebagian besar penduduknya bermata pencaharian sebagai petani dengan komoditas pertanian yang dibudidayakan salah satunya tanaman perkebunan lada. Kabupaten Lampung Lampung Timur merupakan salah satu sentra produksi tanaman lada yang memperoleh dukungan pengembangan tanaman lada nasional sebesar 550 hektar pada tahun 2016 dan merupakan salah satu daerah sentra lada hitam dengan luas lahan perkebunan mencapai 4.815 ha (Ditjenbun 2016).
Produksi lada di Kabupaten Lampung Timur beberapa tahun terakhir mengalami penurunan. Hal ini diantaranya diakibatkan kesalahan pemilihan jenis lada, kurangnya pemeliharaan, kurangnya ketersediaan bibit unggul, dan lemahnya permodalan yang dimiliki petani (Ditjenbun 2014). Menurut Suwanto (2017) permasalahan petani lada Lampung Timur adalah sebagian besar pengelolaan perkebunan rakyat dalam skala kecil dan kemampuan modal yang terbatas. Hal tersebut berdampak pada minimnya penerapan anjuran teknologi termasuk penggunaan bibit unggul, cara budidaya dan penanganan pasca panen. Sebenarnya, untuk meningkatkan jumlah dan mutu lada telah ada pedoman produksi lada yang baik dan benar, yaitu IPC (International Pepper Community) berdasarkan GAP (Good Agriculture Practice) yang meliputi cara pemilihan tanaman sampai dengan penyimpanan produk lada kering, namun masih banyak petani yang belum mengetahui pedoman tersebut. Luas produksi lada cenderung menurun setiap tahun sehingga pemerintah Kabupaten Lampung Timur melalui Dinas Perkebunan menggalakkan intensifikasi tanaman lada dengan memberikan bantuan sarana produksi. Upaya tersebut dilakukan dalam rangka meningkatkan kualitas dan kuantitas lada. 
Desa Sukadana Baru memiliki luas lahan terluas dan jumlah produksi lada terbesar, namun tingkat produktivitas lada berada pada urutan kedua setelah Desa Surya Mataram, yaitu sebesar 0,51 ton/ha dan masih tergolong rendah, mengingat potensi produksi lada hitam sendiri mampu mencapai 4 ton per hektar (BPTP Lampung 2012). Fluktuasi harga komoditas lada sering terjadi, bahkan beberapa tahun terakhir mengalami penurunan. Jatuhnya harga lada menyebabkan hilangnya insentif menanam, dan beralihnya petani menanam komoditas lain sehingga produksi lada menurun (Suwanto 2017).

Menurut Dewi (2017) rendahnya produktivitas juga berkaitan dengan kualitas petani, seperti rendahnya tingkat pendidikan disinyalir merupakan salah satu penyebab rendahnya produktivitas petani. Pendidikan petani berkaitan dengan pengetahun yang mereka miliki, sementara itu keterlibatan akses terhadap informasi adalah kunci dalam peningkatan pengetahuan, dengan kata lain jika seseorang yang memiliki informasi yang memadai maka hal itu akan berdampak kepada tingkat pengetahuannya.

Petani sebagai pengelola utama usaha perkebunan lada keberhasilannya sangat tergantung kepada cara yang mereka lakukan, bagaimana perilaku petani, bagaimana petani berkomunikasi. Atas dasar tersebut diindikasikan faktor-faktor yang mempengaruhi perilaku komunikasi petani seperti komunikasi intepersonal, komunikasi dalam kelompok dan keterdedahan pada media informasi (Puttileihalat 2007).

Setiap petani memiliki kemampuan yang berbeda, hal ini sangat tergantung kepada karakteristik yang mereka miliki, sehingga perilaku komunikasinya pun akan berbeda, karakter tersebut seperti tingkat umur, pendidikan, luas lahan, pendapatan, dan lama berusahatani. Berdasarkan uraian di atas, maka tujuan penelitian ini adalah untuk mengetahui perilaku komunikasi petani lada, mengetahui karakteristik petani lada dan menganalisis hubungan karakteristik petani dengan perilaku komunikasi petani dalam pemenuhan kebutuhan informasi usahatani lada.

\section{METODE PENELITIAN}

Penelitian ini dilakukan menggunakan metode survei di Desa Sukadana Baru, Kecamatan Marga Tiga, Kabupaten Lampung Timur. Lokasi ini dipilih secara sengaja (purposive) dengan pertimbangan Desa Sukadana Baru merupakan desa dengan luas dan jumlah produksi lada terbesar, namun terdapat kesenjangan antara produksi aktual petani dengan produksi potensial.

Penentuan jumlah sampel mengacu pada teori Arikunto (2013), jika jumlah populasinya besar maka jumlah sampel dapat diambil antara $10-15$ persen atau 20 - 25 persen atau lebih. Sampel yang akan diambil pada penelitian ini merupakan jumlah paling minimum, yaitu sebesar 10 persen dari populasi, dikarenakan sampel yang dipilih diperkirakan telah mewakili fenomena atau sifatsifat populasi. Populasi dalam penelitian ini adalah 432 petani lada yang diambil dari jumlah petani yang tergabung dalam 18 kelompok tani di Desa Sukadana Baru, maka jumlah sampel petani lada dapat dihitung dengan rumus pengukuran sampel, Gay dan Diehl (1992) dalam Arikunto (2013):

$\mathrm{n}=0,1 \times \mathrm{N}$

Keterangan:

$\mathrm{n}=$ Jumlah sampel

$\mathrm{N}=$ Jumlah populasi

Berdasarkan persamaan 1, maka perhitungan jumlah sampel untuk petani lada sebagai berikut: $\mathrm{n}=0,1 \times 432=43,2 \approx 43$

Sampel dari masing-masing populasi anggota kelompok tani ditentukan menggunakan rumus alokasi proporsi sampel, Nazir (1988):

$\mathrm{ni}=\left[\frac{\mathrm{Ni}}{\mathrm{N}}\right] \mathrm{n}$

Keterangan:

ni $=$ Jumlah sampel setiap kelompok

$\mathrm{Ni}=$ Jumlah populasi masing-masing kelompok

$\mathrm{N}=$ Jumlah seluruh populasi kelompok

$\mathrm{n}=$ Jumlah sampel secara keseluruhan

Pengambilan data dilakukan pada bulan Agustus 2018. Jumlah sampel sebesar 43 orang petani lada dari 18 proporsi kelompok tani. Penentuan sampel menggunakan tabel acak sederhana sehingga setiap unit sampel populasi mempunyai kesempatan yang sama untuk terpilih menjadi sampel. Jenis data yang digunakan dalam penelitian ini adalah data primer dan data sekunder. Penelitian ini dilakukan dengan wawancara dan pengamatan langsung di lapang. Metode pengumpulan data primer diperoleh melalui wawancara langsung dengan petani responden menggunakan kuesioner (daftar pertanyaan). Data sekunder diperoleh dari lembaga atau instansi terkait seperti Badan Pusat 
Statistik, Kementrian Pertanian, Badan Penyuluhan Pertanian, jurnal, skripsi, publikasi dan pustaka lainnya yang terkait dan relevan dengan penelitian. Pengumpulan data dilakukan dengan beberapa teknik, yaitu observasi berperan serta, dan melakukan pengamatan secara cermat terhadap perilaku responden, wawancara dengan melakukan komunikasi secara langsung kepada responden yang memungkinkan bagi peneliti untuk mengadakan kontak secara langsung, dan data lapangan dibuat secara cermat, rinci dan komprehensif, menggunakan tiga bentuk catatan yaitu rekaman, tulisan dan ingatan. Peneliti mengumpulkan data, membaca, dan mempelajari berbagai macam bentuk data baik tertulis maupun tidak tertulis.

Analisis deskriptif digunakan untuk menjawab tujuan pertama dan ke dua. Analisis tujuan ketiga digunakan uji korelasi berjenjang rank Spearman. Uji korelasi rank Spearman ( $r s$ ) berfungsi untuk menentukan besarnya hubungan antara dua variabel yang berskala ordinal atau tata jenjang. Uji koefisien korelasi jenjang Spearman untuk mengukur hubungan dan membuktikan hipotesis hubungan antara variabel X (karakteristik petani), yaitu umur (X1), pendidikan (X2), luas lahan (X3), lama usahatani (X4), dan pendapatan (X5) dengan variabel Y (perilaku komunikasi petani) yang mencakup komunikasi petani secara interpersonal, komunikasi petani dalam kelompok, dan keterdedahan pada media. Data yang diteliti merupakan data berpasangan dari populasi yang sama. Uji korelasi rank Spearman yang digunakan pada penelitian ini juga selaras dengan uji yang digunakan pada penelitian Meutiara, Nurmayasari, dan Prayitno (2017).

\section{HASIL DAN PEMBAHASAN}

\section{Keadaan Umum Responden}

Ada empat jenis pekerjaan responden, di antaranya responden yang hanya bekerja sebagai petani lada, responden yang melalukan kegiatan usahatani selain lada (usahatani pisang, jagung, kakao, kelapa sawit dan ternak ayam), responden yang bekerja di luar usahatani namun masih dalam bidang pertanian (off farm), dan responden yang juga bekerja diluar pertanian (non farm), seperti pedagang, penyuluh agama, meubel, dan karyawan swasta. Sebagian besar petani memiliki jumlah anggota keluarga sebanyak $4-5$ orang $(53,49 \%)$. Rata- rata jumlah anggota keluarga responden sebanyak empat orang yang terdiri dari seorang istri dan dua sampai tiga orang anak.

\section{Deskripsi Variabel X (Karakteristik Petani Lada)}

Responden dalam penelitian ini adalah petani yang berusahatani lada di Kecamatan Marga Tiga tahun 2018. Karakteristik responden dalam penelitian ini dapat dilihat berdasarkan umur, tingkat pendidikan formal, lama usahatani, luas lahan dan pendapatan petani lada dalam satu tahun terakhir.

\section{Sebaran Responden Menurut Umur}

Responden memiliki kisaran umur 30 - 62 tahun, rata-rata umur responden ialah 42 tahun yang artinya seluruh responden termasuk dalam kategori produktif. Mantra (2004) menjelaskan bahwa penduduk usia 15 - 64 tahun adalah kelompok penduduk usia produktif. Usia produktif merupakan usia yang ideal untuk bekerja dengan baik dan masih kuat untuk melakukan kegiatan yang memerlukan tenaga.

\section{Sebaran Responden Menurut Lama Pendidikan Formal}

Pendidikan formal yang ditempuh petani mulai dari Sekolah Dasar (9 tahun), Sekolah Menengah ( $>9$ tahun hingga 12 tahun), hingga Sekolah Tinggi (>12 tahun). Rata-rata petani responden merupakan lulusan Sekolah Dasar. Petani mengaku, hal tersebut terjadi karena pada saat itu hanya sedikit fasilitas pendidikan yang tersedia. Untuk menempuh pendidikan yang lebih tinggi, petani harus keluar dari desa dengan jarak tempuh yang cukup jauh, serta keterbatasan perekonomian

\section{Sebaran Responden Menurut Luas Lahan}

Berdasarkan hasil penelitian yang diperoleh, luas lahan garapan terkecil yang dimiliki petani adalah 0,25 ha dan luas lahan garapan terbesar yang dimiliki petani adalah 7,00 ha dengan jarak tanam pohon 2,5x2 meter, dan status kepemilikan lahan seluruhnya adalah milik sendiri. Mayoritas luas lahan petani responden sebesar 2,00 ha dan masuk ke dalam klasifikasi lahan sempit. Rata-rata jumlah batang lada yang diusahakan responden adalah 1.600 batang per hektar serta umur pohon rata-rata 19 tahun.

\section{Sebaran Responden Menurut Lama Usahatani}

Rata rata petani responden telah berusahatani lada selama 22 tahun. Petani-petani tersebut kebanyakan adalah petani yang mengelola usahatani ladanya karena melanjutkan usahatani 
yang sebelumnya dijalankan oleh orang tuanya atau sebagai hasil dari pembagian warisan. Hal tersebut menunjukkan bahwa usahatani lada secara turun temurun dikelola oleh keluarga. Lamanya berusahatani lada secara tidak langsung akan berpengaruh terhadap kemampuan dan keterampilan dalam mengelola usahatani mereka. Pengaruh yang terlihat adalah terhadap teknis budidaya dan hasil produksi lada nantinya. Lama usahatani responden yang telah dilalui dapat memberikan kemampuan kepada responden dalam menggunakan faktor-faktor produksi yang ada.

\section{Sebaran Responden Menurut Pendapatan}

Berdasarkan data yang diperoleh dari lapangan diketahui bahwa pendapatan total petani yang bersumber dari kegiatan usahatani lada, usahatani nonlada, off farm, dan non farm yang dihasilkan petani tertinggi adalah Rp190.560.500,00/tahun atau Rp15.880.041,00/bulan dan terendah Rp3.723.000,00/tahun atau Rp310.250,00/bulan. Pendapatan petani responden dibagi ke dalam empat kategori menurut BPS, yaitu rendah, sedang, tinggi, dan sangat tinggi. Mayoritas pendapatan petani berada pada klasifikasi sedang, yaitu sebanyak 15 orang $(34,88 \%)$. Rata rata pendapatan seluruh responden sejumlah Rp2.591.382,00/bulan, yang tergolong dalam klasifikasi tinggi. Pendapatan petani sebagian besar diperoleh dari hasil usahatani lada. Responden yang berada pada klasifikasi sedang dan tinggi memiliki usaha atau pekerjaan sampingan, hal ini sejalan dengan hasil penelitian Aprilina, Nurmayasari, Rangga (2017).

\section{Deskripsi Variabel Y (Perilaku Komunikasi Petani Lada)}

Perilaku komunikasi responden dalam penelitian ini merupakan tindakan atau respon petani dalam lingkungan atau situasi komunikasi yang ada di Desa Sukadana Baru, Kecamatan Marga Tiga, Kabupaten Lampung Timur. Berdasarkan hasil di lapangan bahwa secara keseluruhan perilaku komunikasi petani dapat dilihat pada Tabel 1 .

Sebagian besar petani memiliki perilaku komunikasi dalam klasifikasi sedang, yaitu sebanyak 30 orang $(69,77 \%)$. Informasi mengenai usahatani lada yakni mencakup penanaman, perlakuan/pengunaan bibit, pemupukan dan pengendalian hama dan penyakit, pemeliharaan, panen dan pasca panen dan, informasi harga sebagai informasi tambahan
Tabel 1. Sebaran petani responden berdasarkan skor pada perilaku komunikasi

\begin{tabular}{|c|c|c|c|}
\hline Klasifikasi & Skor & $\sum$ & $\%$ \\
\hline Rendah & $14,77-18,52$ & 8 & 18,60 \\
\hline Sedang & $18,53-22,27$ & 30 & 69,77 \\
\hline \multirow[t]{2}{*}{ Tinggi } & $22,28-26,02$ & 5 & 11,63 \\
\hline & Jumlah & 43 & 100,00 \\
\hline
\end{tabular}

Berbagai informasi terkait usahatani, rata rata petani memenuhi informasi dari petani lain dan kelompok tani, sedangkan tengkulak hanya memberikan informasi terkait harga dan waktu panen lada. Hal ini dilihat dari petani yang lebih banyak mengetahui tentang teknis usahatani melalui hubungan komunikasi interpersonal dan komunikasi kelompok serta masih cukup minim informasi yang diperoleh dengan mendedahkan diri pada berbagai jenis media.

Petani mengakui lebih banyak memperoleh informasi yang dapat menambah pengetahuannya melalui orang orang yang dapat ditemui dan berkomunikasi secara langsung, daripada mencari informasi melalui media massa dan gabungan berbagai media massa, baik dari televisi, radio dan surat kabar. Hal ini sejalan dengan penelitian Oktavia, Muljono, Amanah, dan Hubeis (2017) bahwa sedikitnya jumlah pelaku agribisnis yang selalu menggunakan media massa untuk mencari informasi, karena informasi kurang relevan dengan kebutuhan dan terbatasnya akses terhadap jaringan internet.

Berbagai sumber informasi yang diterima petani mengenai usahatani sangat membantu dalam melakukan kegiatan usahatani lada. Perilaku komunikasi petani berdasarkan sumber informasi dapat dilihat pada Tabel 2 yang terdiri dari indikator pencarian informasi melalui komunikasi interpersonal, komunikasi dalam kelompok, dan keterdedahan pada media. Sebagian besar petani dalam pencarian informasi pada saluran komunikasi interpersonal dengan berbagai sumber termasuk tinggi, terutama komunikasi interpersonal dengan tengkulak, dan petani lain. Frekuensi rata rata petani malakukan komunikasi interpersonal dengan tengkulak, dan penyuluh sebanyak satu kali dalam setahun, sedangkan dengan petani lain sebanyak 35 kali dalam setahun, baik petani dari dalam maupun dari luar desa. Hal ini menunjukkan bahwa sebagaian petani selalu berkomunikasi dan bertukar informasi dengan sesama petani. 
Tabel 2. Perilaku komunikasi petani berdasarkan sumber informasi

\begin{tabular}{|c|c|c|c|c|}
\hline Indikator & Sumber & $\sum$ & $\%$ & $\begin{array}{l}\text { Klasi- } \\
\text { fikasi }\end{array}$ \\
\hline Komunikasi & - Tengkulak & 43 & 100,00 & $\mathrm{~T}$ \\
\hline secara & - PPL & 34 & 79,07 & $\mathrm{~T}$ \\
\hline \multirow[t]{3}{*}{ interpersonal } & - Petani lain & 43 & 100,00 & $\mathrm{~T}$ \\
\hline & - Instansi & 15 & 34,88 & S \\
\hline & $\begin{array}{l}\text { - Pertemuan } \\
\text { rutin }\end{array}$ & 43 & 100,00 & $\mathrm{~T}$ \\
\hline \multirow[t]{3}{*}{$\begin{array}{l}\text { Komunikasi } \\
\text { dalam } \\
\text { kelompok }\end{array}$} & $\begin{array}{l}\text { - Di luar } \\
\text { pertemuan } \\
\text { rutin }\end{array}$ & 41 & 95,35 & $\mathrm{~T}$ \\
\hline & - Pelatihan & 32 & 74,42 & $\mathrm{~T}$ \\
\hline & - Radio & - & 0,00 & $\mathrm{R}$ \\
\hline Keterdedahan & $-\mathrm{TV}$ & - & 0,00 & $\mathrm{R}$ \\
\hline \multirow[t]{4}{*}{ pada media } & - Internet & 35 & 81,40 & $\mathrm{~T}$ \\
\hline & - Koran & 2 & 4,65 & $\mathrm{R}$ \\
\hline & - Brosur & - & 0,00 & $\mathrm{R}$ \\
\hline & - Majalah & 7 & 16,28 & $\mathrm{R}$ \\
\hline $\operatorname{san}$ & & 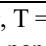 & ggi & \\
\hline
\end{tabular}

Sebagian besar petani dalam pencarian informasi pada saluran komunikasi interpersonal dengan berbagai sumber termasuk tinggi, terutama komunikasi interpersonal dengan tengkulak, dan petani lain. Frekuensi rata rata petani malakukan komunikasi interpersonal dengan tengkulak, dan penyuluh sebanyak satu kali dalam setahun, sedangkan dengan petani lain sebanyak 35 kali dalam setahun, baik petani dari dalam maupun dari luar desa. Hal ini menunjukkan bahwa sebagaian petani selalu berkomunikasi dan bertukar informasi dengan sesama petani.

Kehadiran petani dalam setiap pertemuan rutin kelompok adalah sebesar 100 persen. Petani mengikuti kegiatan di luar pertemuan rutin kelompok sebesar 95,35 persen dengan rata rata petani mengikuti sebanyak 10 kali kegiatan dalam setahun seperti gotong royong, arisan, pengajian, dan kegiatan sosial. Petani mengikuti berbagai pelatihan yang diadakan kelompok sebesar 74,42 persen dengan rata rata petani mengikuti pelatihan sebanyak 1 kali dalam setahun seperti penyuluhan, pelatihan pembibitan, dan pengembangan produk. Selain kegiatan penyuluhan, beberapa instansi juga pernah mengunjungi petani, di antaranya STIPER Dharma Wacana Metro, Dinas Pariwisata, dan Dinas Industri.

Hal ini menunjukkan bahwa sebagian besar petani responden telah menyadari akan pentingnya kegiatan kelompok. Frekuensi kehadiran petani dalam setiap kegiatan yang diadakan oleh kelompok tani menimbulkan efek pada petani di dalam memperoleh informasi untuk memecahkan masalah atau mengambil keputusan dalam mengelola usahatani ladanya.

Sebagian besar petani telah menggunakan sarana teknologi informasi dengan mudah. Khusus handphone seluruh petani memiliki dan menggunakan untuk menelepon atau mengirim pesan. Selain digunakan untuk menelpon dan mengirim pesan, handphone digunakan petani untuk mengakses internet karena mudah, lengkap dan beragam, serta cepat.

Keterdedahan pada media masa elektronik seperti radio, dan TV, kebanyakan petani mengaku tidak tersedia informasi mengenai pengelolaan usahatani lada, sehingga lebih banyak hanya mendengarkan dan melihat berita dan hiburan. Dampak dari media massa tampaknya tidak terjadi untuk semua anggota tetapi tergantung para variabel variabel lain (Severin dan Tankard 2005). Sebanyak 16,28 persen petani memperoleh informasi usahatani lada dari majalah petanian. Umumnya petani jarang membaca media cetak (koran, brosur, majalah), mereka membaca jika memang tersedia dan mengaku tidak tersedia informasi mengenai usahatani lada pada kebanyakan media cetak.

Fuady, Lubis dan Lumintang (2012) menyatakan bahwa rendahnya akses petani terhadap informasi melalui media massa disebabkan beberapa faktor, antara lain, kurangnya informasi pertanian yang dimuat di media massa, petani kurang memiliki waktu yang cukup untuk mengakses media massa, terlebih media elektonik yang penayangannya di saat petani masih bekerja, dan rendahnya minat petani untuk mengakses media massa.

\section{Pengujian Hipotesis (Hubungan Karakteristik dan Perilaku Komunikasi Petani Lada)}

Hipotesis penelitian ini adalah terdapat hubungan antara karakteristik petani yang mencakup usia, pendidikan, luas lahan, lama usahatani dan pendapatan dengan perilaku komunikasi. Hasil pengolahan data dengan menggunakan aplikasi SPSS 16.0 For Windows dengan menggunakan Uji Spearman (rs) pada taraf alfa 0,05 menghasilkan hubungan karakteristik petani dengan perilaku komunikasi dapat dilihat pada Tabel 3. Tabel 3 menunjukkan bahwa ada hubungan antara variabel perilaku komunikasi dengan variabel karakteristik petani. Karakter tersebut diantaranya, umur, luas lahan, dan pendapatan. Variabel yang tidak berhubungan dengan perilaku komunikasi adalah lama usahatani. 
Tabel 3. Hasil analisis hubungan antara perilaku komunikasi dengan karakteristik petani lada

\begin{tabular}{clcc}
\hline $\begin{array}{c}\text { Variabel } \\
\text { Y }\end{array}$ & \multicolumn{1}{c}{$\begin{array}{c}\text { Variabel } \\
\mathrm{X}\end{array}$} & $\begin{array}{c}\text { Koefisien } \\
\text { korelasi (r) }\end{array}$ & $\begin{array}{c}\text { Signifikansi } \\
(p \text {-value })\end{array}$ \\
\hline \multirow{3}{*}{ - Umur } & $0,336^{*}$ & 0,028 \\
Perilaku & - Pendidikan & $-0,148$ & 0,345 \\
Komunikasi & - Luas Lahan & $0,321^{*}$ & 0,036 \\
& Lama & 0,255 & 0,100 \\
& usahatani & & \\
\multicolumn{2}{l}{ - Pendapatan } & $0,402^{*}$ & 0,007 \\
\hline Keterangan : "Nyata pada taraf $\alpha 0,05$ &
\end{tabular}

Berdasarkan hasil uji statistik diperoleh nilai koefisien korelasi sebesar 0,336 signifikansi 0,028 kurang dari alfa 0,05 , maka dapat diambil kesimpulan terima $\mathrm{H}_{1}$. Umur berhubungan nyata dengan perilaku komunikasi, artinya adalah semakin bertambah umur petani semakin bertambah pula intensitas komunikasi interpersonal, komunikasi dalam kelompok serta mendedahkan diri pada media sebagai sumber informasinya. Hal ini didukung dengan fakta di lapangan bahwa petani dengan umur yang tergolong sudah tua pun masih tetap aktif mencari informasi dengan mendedahkan diri pada media. Sejalan dengan hasil penelitian Hilman (2010), bahwa usia berhubungan nyata secara positif dengan kebutuhan informasi, artinya adalah semakin bertambah usia petani semakin bertambah pula intensitas penggunaan media sebagai sumber informasi.

Berdasarkan hasil uji statistik diperoleh nilai koefisien korelasi sebesar $-0,148$ signifikansi 0,345 lebih dari alfa 0,05, maka dapat diambil kesimpulan terima $\mathrm{H}_{0}$. Pendidikan tidak mempunyai hubungan yang nyata dengan perilaku komunikasi petani karena pada pendidikan formal petani tidak memperoleh materi mengenai budidaya lada, selain itu kebanyakan petani mengaku telah cukup puas dengan informasi dan pengetahuan yang mereka miliki terkait usahatani lada yang telah diajarkan secara turun menurun. Hal ini sejalan dengan hasil penelitian Puttileihalat (2007) bahwa untuk memperoleh informasi minyak kayu putih bukan dilihat dari tingginya pendidikan seseorang, namun didasarkan pada pengetahuan petani tentang objek tersebut. Petani dengan jenjang pendidikan tinggi ternyata tidak selalu mencari informasi pengelolaan usahatani ladanya, dan tidak sedikit pula petani yang justru hanya lulusan sekolah dasar yang lebih aktif memenuhi informasi terkait usahatani ladanya.
Berdasarkan hasil uji statistik diperoleh nilai koefisien korelasi sebesar 0,321 signifikansi 0,036 kurang dari alfa 0,05 , maka dapat diambil kesimpulan terima $\mathrm{H}_{1}$. Luas lahan berhubungan nyata dengan perilaku komunikasi, artinya adalah semakin luas lahan yang dimiliki petani semakin bertambah pula intensitas komunikasi interpersonal, komunikasi dalam kelompok serta mendedahkan diri pada media sebagai sumber informasinya. Hal ini disebabkan karena petani melakukan pekerjaan sebagai petani lada sebagai sumber utama mata pencahariannya. Besarnya luas lahan sangat menentukan produksi yang dicapai oleh sebab itu petani berusaha untuk memperoleh informasi mengenai usahatani lada sebanyak banyaknya dari berbagai sumber untuk dapat mengembangkan usahataninya. Hal ini sejalan dengan hasil penelitian Sasongko, Witjaksono, dan Harsoyo (2014), bahwa semakin luas lahan yang dimiliki oleh petani, maka sikap petani akan semakin positif karena adanya kecenderungan untuk melakukan kegiatan usahatani yang lebih efektif dan efisien.

Berdasarkan hasil uji statistik diperoleh nilai koefisien korelasi sebesar 0,255 signifikansi 0,100 lebih dari alfa 0,05, maka dapat diambil kesimpulan terima $\mathrm{H}_{0}$. Lama usahatani tidak mempunyai hubungan yang nyata dengan perilaku komunikasi petani. Hasil penelitian di lapangan petani mengaku pada umumnya mereka mulai melakukan kegiatan bertani "sejak kecil" dan berkelanjutan hingga saat ini. Rata- rata lama usahatani responden adalah 22 tahun dan tidak diikuti dengan perkembangan usahatani karena petani mengaku telah cukup puas mengikuti cara berusahani yang telah diajarkan secara turun temurun.

Berdasarkan hasil uji statistik diperoleh nilai koefisien korelasi sebesar 0,402 signifikansi 0,007 kurang dari alfa 0,05, maka dapat diambil kesimpulan terima $\mathrm{H}_{1}$. Pendapatan petani berhubungan nyata dengan perilaku komunikasi, artinya adalah semakin tinggi pendapatan yang diperoleh petani semakin bertambah pula intensitas komunikasi interpersonal, komunikasi dalam kelompok serta mendedahkan diri pada media sebagai sumber informasinya. Hal ini didukung dengan fakta di lapangan bahwa petani dengan pendapatan tinggi cenderung lebih aktif dalam mencari informasi, hal ini dikarenakan petani menyadari keberhasilan usahatani mereka dapat semakin membaik apabila didukung dengan pengetahun yang lebih banyak. 


\section{KESIMPULAN}

Seluruh responden penelitian berada pada tingkat umur produktif dengan umur rata rata 42 tahun, seluruh responden pernah bersekolah dengan rata rata bersekolah sampai tingkat pendidikan dasar (9 tahun), rata-rata luas lahan yang diusahakan petani ke dalam kategori sempit, yaitu 2,00 hektar, lama berusahatani lada responden rata-rata 22 tahun, dan rata-rata pendapatan responden adalah Rp2.591.382,00/bulan. Rata-rata perilaku komunikasi responden penelitian adalah sedang. Pada komunikasi interpersonal, responden lebih banyak memenuhi kebutuhan informasi usahatani dari teman, petani lain, dan kelompok tani. Pada komuniksi dalam kelompok seluruh responden aktif memenuhi kebutuhan informasi usahatani melalui kegiatan rutin kelompok, kegiatan di luar kegitan rutin dan pendidikan nonformal yang diadakan kelompok. Sebagian besar responden penelitian hanya terdedah pada media elektronik melalui internet, dan hanya sedikit yang terdedah pada media cetak. Terdapat hubungan yang nyata antara perilaku komunikasi dalam pemenuhan informasi usahatani lada, dengan umur petani, luas lahan, dan pendapatan.

\section{DAFTAR PUSTAKA}

Aprilina DS, Nurmayasari I, dan Rangga KK. 2017. Keefektifan komunikasi kelompok tani dalam penerapan program jarwobangplus di Kecamatan Gading Rejo Kabupaten Pringsewu. JIIA, 2 (5) 211-218. http://jurnal. fp.unila.ac.id/index.php/JIA/article/view/1661 /1487. [4 September 2018].

Arikunto S. 2013. Prosedur penelitian Suatu Pendekatan Praktik. Rineka Cipta. Jakarta.

Balai Pengkajian Teknologi Pertanian Lampung. 2012. Budidaya Tanaman Lada. BPTP Lampung.

Dewi R. 2017. Faktor faktor yang mempengaruhi produktivitas usaha tani dan keberhasilan program simantri di Kabupaten Klungkung. Jurnal Ekonomi dan Bisnis. 6 (2):701-728. https://ojs.unud.ac.id/index.php/EEB/article/vi ew/24578/17167. [02 Oktober 2018]

Ditjenbun. 2012. Statisktik Perkebunan Indonesia. Direktorat Jenderal Perkebunan. Jakarta.

Ditjenbun. 2014. Pedoman Teknis Pengembangan Tanaman Lada. Direktorat Jenderal Perkebunan. Jakarta.

Ditjenbun. 2016. Statistik Perkebunan Indonesia Komoditas Lada Tahun 2015-2017. Direktorat Jendral Perkebunan. Jakarta.
Fuady I, Lubis DP, dan Lumintang RWE. 2012. Perilaku komunikasi petani dalam pencarian informasi pertanian organik (kasus petani bawang merah di Desa Srigading Kabupaten Bantul) . Jurnal Komunikasi Pembangunan, 2 (10):10-18. http://journal.ipb.ac.id/index.php /jurnalkmp/article/view.[12 Desember 2017].

Hilman C. 2010. Hubungan karakteristik petani dengan sumber dan kebutuhan informasi untuk pengembangan agribisnis (studi kasus petani padi di Desa Padahurip Kecamatan Banjarwangi Kabupaten Garut). Skripsi. Fakultas Pertanian Institut Pertanian Bogor. Bogor. https://repository.ipb.ac.id/handle/ 123456789/26983. [12 Desember 2017].

Mantra BI. 2004. Demografi Umum. Pustaka Pelajar. Yogyakarta.

Meutiara A, Nurmayasari I, dan Prayitno RT. 2017. Jaringan komunikasi petani dalam adopsi inovasi pertanian tanaman pangan di Desa Rejo Binangun Kecamatan Raman Utara, Kabupaten Lampung Timur. JIIA, 3 (5) 320-327. http://jurnal.fp.unila.ac.id/index.php/ JIA/article/view/1645/1471. [4 September 2018].

Nazir M. 1988. Metode Penelitian. Ghalia Indonesia. Jakarta.

Oktavia Y, Muljono P, Amanah S, dan Hubeis M. 2017. Hubungan perilaku komunikasi dan pengembangan kapasitas perilaku agribisnis perikanan air tawar di Padang, Sumatera Barat. Jurnal Penyuluhan, 2 (13) 157-165. http://journal.ipb.ac.id/index.php/jupe/article/ view/15443. [21 September 2018].

Puttileihalat PM. 2007. Hubungan perilaku komunikasi dengan perilaku usahatani petani minyak kayu putih. Tesis. Institut Pertanian Bogor.Bogor. https://repository.ipb.ac.id/han dle/123456789/43842. [10 Oktober 2018]

Sasongko WA, Witjaksono R, dan Harsoyo. 2014. Pengaruh perilaku komunikasi terhadap sikap dan adopsi teknologi budidaya bawang merah di lahan pasir pantai Kecamatan Sanden Kabupaten Bantul. Agro Ekonomi, 1 (24) 35-43. https://jurnal.ugm.ac.id/jae/article/ view/17380/11313. [12 Desember 2017].

Severin WJ dan Tankard JW. 2005. Teori Komunikasi Sejarah, Metode, dan Terapan di Dalam Media Massa. Prenada media. Jakarta.

Suwanto. 2017. Analisis daya saing dan pemasaran lada hitam di Kabupaten Lampung Timur. Tesis. Magister Agribisnis. Universitas Lampung. 